\title{
Design Analysis of Solar-Powered Unmanned Aerial Vehicle
}

\author{
Karthik Reddy Buchireddy Sri¹, Poondla Aneesh¹, Kiran Bhanu¹, M Natarajan¹
}

\begin{abstract}
One of the main problems in micro unmanned aerial vehicles is endurance or flight time since the general domain aircraft uses conventional fuel, which is a pollutant, has a limited life and is costly. Then, there is a huge demand for using an unlimited non-exhaustible source of energy. Solar energy is one of the unlimited available renewable energy which can be used to increase the endurance of unmanned aerial vehicle without adding significant mass or increasing the size of the fuel system. This paper aims to encourage research on renewable energy sources for aviation considering the basic challenges for a solar-powered aircraft: geographical area of operation, energy collection and storage, payload and design parameters. Hence, a plane is designed for $2 \mathrm{~kg}$, including payload, and is analyzed in various aspects. Besides, the design is optimized starting from airfoil to complete structure for better performance.
\end{abstract}

KEYWORDS: Solar cell, Unmanned aerial vehicle, Renewable energy, Endurance, Conceptual design.

\section{INTRODUCTION}

In today's world, there are more than 11,000 unmanned aerial vehicles (UAVs) in service (or planned for future services) by the Military for various purposes (Kumar et al. 2015). These vehicles can fly remotely as well as autonomously. In spite of their usage in various applications, they lack in performance because of power restrictions, which means they either have to land to refuel or to depend on another UAV to complete the task.

Nowadays the ability to fly without using conventional fossil fuels is primarily focused in recent years, both in application point of view and scientific field since the major concerns are an increase in global warming and a decrease in natural resources. Since then, the use of electric aircraft has been widespread but here the crucial issue is their high power consumption when compared with their limited energy storage capability, which leads to an endurance that can rarely exceed half an hour. Increasing the size of the battery or incorporating more batteries increases the weight of the plane, which affects the flight time of the UAV as it is inversely proportional. So, now, the ability to fly an aircraft to increase the endurance limit has been a key issue in both UAVs and civilian aviation.

One of the possibilities to increase the flight time is by using unlimited solar energy through solar cells. These cells, by connecting them with an electronic circuit, can provide sufficient power for motor and the electronics and, if in excess, it can also be stored in the battery; here the battery can be used as a buffer when flying in darkness or under clouds. Hence, the possible solution to enhance the endurance is by using solarpowered aircraft driven by electric-based propulsion systems in which the power is supplied continuously throughout the

\footnotetext{
三 1.VIT University - School of Mechanical Engineering Mechanical Department - Vellore/Tamil Nadu - India.

Author for correspondence: Karthik Reddy Buchireddy Sri | VIT University - School of Mechanical Engineering Mechanical Department | Near Katpadi Road | Vellore - Tamil Nadu 632014 - India | Email: bskarthikreddy@gmail.com

Received: 04/17/2016 | Accepted: 06/21/2016
} 
day by the unlimited solar energy, which can eliminate fuel and also solve the limited energy storage capability problem.

This paper studies the complete design of a solar-powered $\mathrm{UAV}$, which is mostly designed for low-altitude long-endurance (LALE) applications.

The main principle is to make use of available unlimited solar energy by converting it into electricity through solar cells. When sunlight strikes the solar cell, the cell creates electrons and holes as charge carriers and, when a circuit is made, the free electrons pass through a certain load in order to recombine with holes and, in this way, the current is generated. Here, by arranging solar cells in series on the top of the wing and then wrapping the entire wing with transparent material for the safety of solar cells during flight, cells are arranged in series to get the required voltage in order to safely charge the $3 \mathrm{~S}$ battery; from there, the battery power is supplied to the motor for throttling during constant level flight. In this study, the aircraft was assumed to be a glider, which means it also stores the energy in the battery during the gliding period. In this way, both flying the plane by using solar energy alone and storing the energy in the battery in order to extend the flight time can be achieved.

\section{DESIGN METHODOLOGY}

The design process of the entire aircraft is composed of two phases: conceptual and preliminary. In conceptual design, the basic configuration arrangement, size, weight, and performance are calculated. Then, designing the CAD modeling of individual parts in order to meet the required targets and optimizing it are done in preliminary design. The design requirements are used to guide and evaluate the development of the overall aircraft configuration. There are two simple balances:

- Weight balance: the lift force has to be equal to the weight of all the elements constituting the airplane.

- Energy balance: the energy that is collected during a day from the solar panel has to be equal to or higher than the electrical energy needed by the airplane during its level flight.

\section{MISSION SPECIFICATIONS}

One of the main aims of this paper is to check whether the power available from the Sun is required to power an aircraft, which, in turn, helps in increasing the endurance of the aircraft from a couple of minutes to hours. Here the gross weight of the plane
(2 kg) is kept constant (Table 1). There was no range requirement since the goal was simply to remain flying, not to reach any destination.

Table 1. Mission specifications.

\begin{tabular}{|c|c|}
\hline Parameter & SI units \\
\hline Gross weight & $2 \mathrm{~kg}$ \\
\hline Payload & $0.5 \mathrm{~kg}$ \\
\hline Altitude & $30-50 \mathrm{~m}$ \\
\hline Average air density & $1.22 \mathrm{~kg} \cdot \mathrm{m}^{-3}$ \\
\hline Clearness factor & $0.7(1=$ clear sky $)$ \\
\hline Take-off distance & None (hand toss launch) \\
\hline
\end{tabular}

\section{ESTIMATION OF THE NUMBER OF SOLAR CELLS REQUIRED AND ITS ARRANGEMENT ON THE WING}

For this design, $3 \mathrm{~S}$ battery has been chosen for two reasons: using more lithium polymer ( $\mathrm{LiPo}$ ) cells in series $(>3 \mathrm{~S})$ requires more voltage to initiate the charging process, leading to an increase in solar cells and wingspan, which, in turn, increases the weight of the model. On the other hand, if less LiPo cells in series (2S) are used, it will be difficult to supply the required power to achieve a good climb rate.

As for charging the $3 \mathrm{~S}$ battery, it requires a constant safe charging voltage of about $12.4 \mathrm{~V}$. This voltage has to be supplied by the solar cells; those selected for this design were Sun power C-60 photovoltaic. The Sun power cells were more efficient than most silicon-based ones. The $22 \%$ efficiency of the C-60 (Table 2)was significantly better than typical silicon solar cells with efficiencies around 15\% (Kederoglu et al. 2012).

According to Table 2, each solar cell gives out $0.57 \mathrm{~V}$, which means 22 solar cells are required to meet the targeted voltage; here, two more cells are added for safe side. These 24 cells should be connected in series to achieve the required voltage.

Since the number of cells is fixed, a minimum area of the wing is calculated. Two possible combinations in arranging

Table 2. Specifications of sun power C-60 solar cell.

\begin{tabular}{|c|c|}
\hline Parameter & SI unit \\
\hline Mass of Solar cell & $0.008 \mathrm{~kg}$ \\
\hline Length and width & $0.125 \times 0.125 \mathrm{~m}$ \\
\hline Area of single solar panel & $0.0150 \mathrm{~m}^{2}$ \\
\hline Efficiency of solar cell & $22 \%$ \\
\hline Rated voltage & $0.57 \mathrm{~V}$ \\
\hline Rated current & $5.37 \mathrm{~A}$ \\
\hline
\end{tabular}

Source: sunpowercorp.com 
these cells in series (Type 1 and Type 2) over the wing can be seen in Fig. 1.

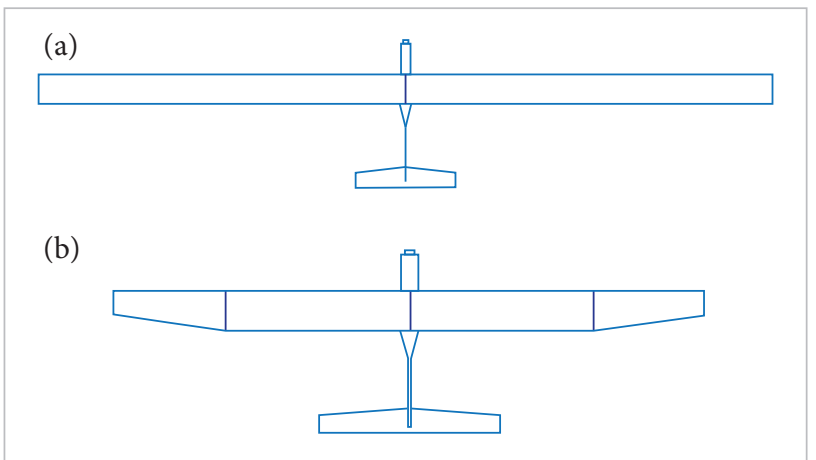

Figure 1. (a) Single row of cells — high-aspect-ratio wing (Type 1); (b) Two rows of cells - medium-aspect-ratio wing (Type ?).

The problems in Fig. 1a are:

- The wing is two long, which requires a tough structure, increasing the weight and cost.

- Controlling will be difficult as it does not have ailerons.

- While connecting the circuit with tapping wire, the 2 ends of the wire are too far, resulting in loss of power efficiency.

In Fig. 1b, all these problems are solved as the solar cells are placed only on the mid wing; the end wings are for stability with a polyhedral angle of about $7^{\circ}$ on both sides, which also includes ailerons for easy control. In Fig. 2, it is observed that, in Type 1, more tapping wire is used in order to close the circuit, which means more loss while transferring the current. In Type 2, this problem is nullified as we can close the circuit with the usage of very less wire.

As each solar cell has $0.125 \mathrm{~m}$ in length, for 12 solar cells in a row, a wingspan (middle portion) of $1.5 \mathrm{~m}$ is required. However, apart from this length, extra space is required for the soldering purpose. Besides, at the ends, at least $2-3 \mathrm{~cm}$ should be left because there will be abnormal forces at the junction. Then, a central wingspan of $1.63 \mathrm{~m}$ was chosen by considering

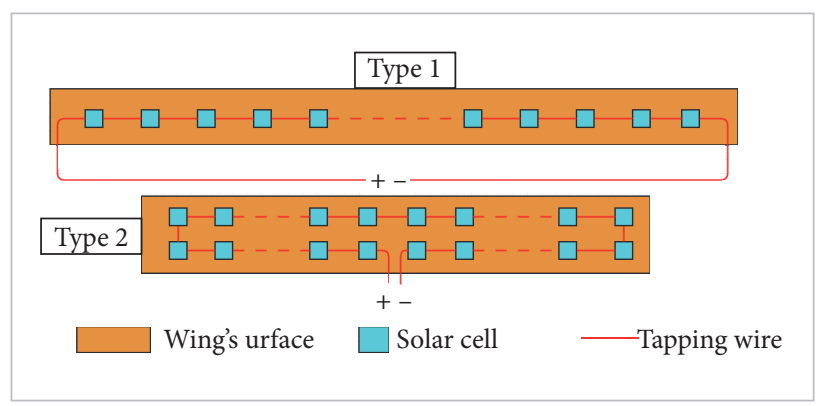

Figure 2. Arrangement and connection of solar cells on the wing. all parameters. The ends of the wing are tapered from a root chord of $30 \mathrm{~cm}$ to a tip one of $20 \mathrm{~cm}$ over a length of $50 \mathrm{~cm}$. The aspect ratio of the entire wing is 9.36 .

\section{AIRFOIL SELECTION}

After finalizing the wing design, the airfoil is selected based on the following requirements: high lift coefficient; low drag coefficient; less camber for cell placement. Here, the 4 airfoils are analyzed, which are taken from previous designs (Bruscoli 2011). The approach to find the airfoil lift and drag is shown in Fig. 3, where the input parameters are aspect ratio (AR) and wingspan (b). The airfoils can be seen in Figs. 4.

For these 4 airfoils, XFLR analysis has been done to select the airfoil with the best performance characteristics. The analysis is done for $30-\mathrm{cm}$ chord length and by keeping the 4-degree angle of attack for all airfoils.

In Fig 5, various graphs have been plotted by comparing the 4 airfoils for the 4-degree angle of attack $(\alpha)$, and the important parameters lift $\left(C_{L}\right)$ and $\operatorname{drag}\left(C_{D}\right)$ coefficients are shown in Table 3. Hence, according to this table, Airfoil-4 WE3.55 is chosen for its best performance as it has high $C_{L} / C_{D}$ ratio, which is the same airfoil designed for Sky-Sailor (Noth 2008).

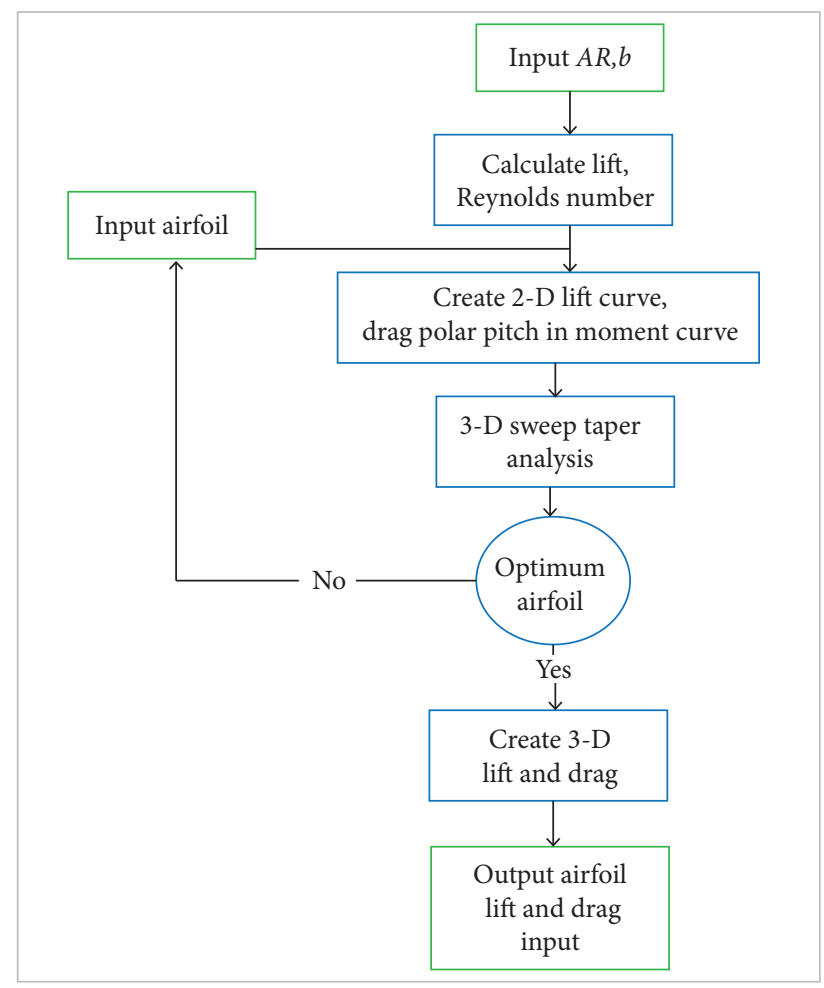

Figure 3. Flowchart to find airfoil lift and drag. 
(a)

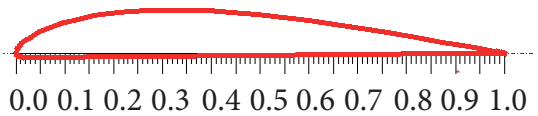

(b)

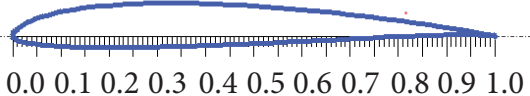

(c)

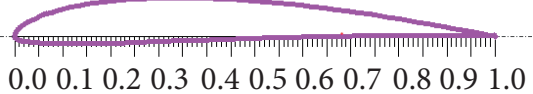

(d)

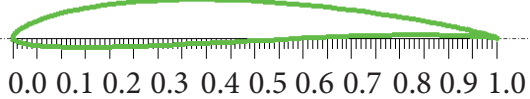

Figure 4. (a) Aquila 9.3\%; (b) Medium 59000 (9\%); (c) 59037 (9\%); (d) WE3.55.

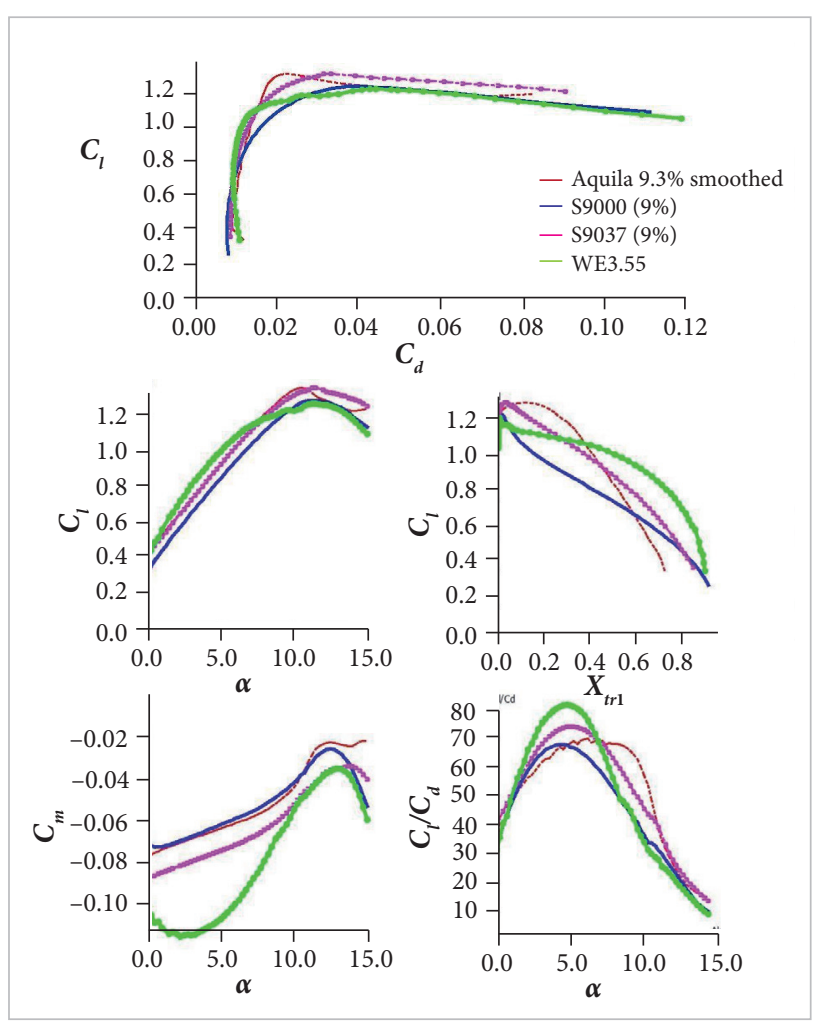

Figure 5. Comparison of airfoil performance.

Table 3. Comparison of the 4 selected airfoils.

\begin{tabular}{|c|c|c|c|c|}
\hline Parameter & $\begin{array}{c}\text { Aquila } \\
9.3 \%\end{array}$ & $\begin{array}{c}\text { Medium } \\
\mathbf{S 9 0 0 0} \\
{[9 \%]}\end{array}$ & $\begin{array}{c}\text { S9037 } \\
{[9 \%]}\end{array}$ & WE3.55 \\
\hline$C_{L}$ & 0.83 & 0.75 & 0.83 & $\mathbf{0 . 9 1}$ \\
\hline$C_{D}$ & $\mathbf{0 . 0 1 3}$ & 0.01127 & 0.116 & 0.0115 \\
\hline$C_{L} / C_{D}$ & 64 & 66.5 & 71 & $\mathbf{7 8 . 5}$ \\
\hline
\end{tabular}

\section{Circuit Diagram}

From the circuit diagram shown in Fig. 6, the energy received from the Sun is collected by the solar panel, which converts it into electricity and then there is the maximum power point tracker (MPPT), which helps in tracking the maximum power of any solar cell and provides it at all times. In MPPT, there are 3 terminals: one is connected to the solar panel; the other, to load (motor); and the last one, to the battery. Then, in level flight, the MPPT sends power directly to the motor from the solar cells and, when gliding, as the motor does not require power, the battery starts charging. If an excess of power is required, during climbing or when the solar intensity is low, the battery supplies the required power, which is stored into the motor. Thus, from the battery, the energy goes to the motor, which rotates the propeller and, between them, there is an electronic speed control (ESC) regulating the speed. Besides the present battery, there is an additional small pencil battery to control the avionics; the reason to separate it is, even if there is any problem in the main circuit or else, any damage in the cells still controlling the plane can be done as the control system's battery is not connected to the main circuit, which helps in safe landing.

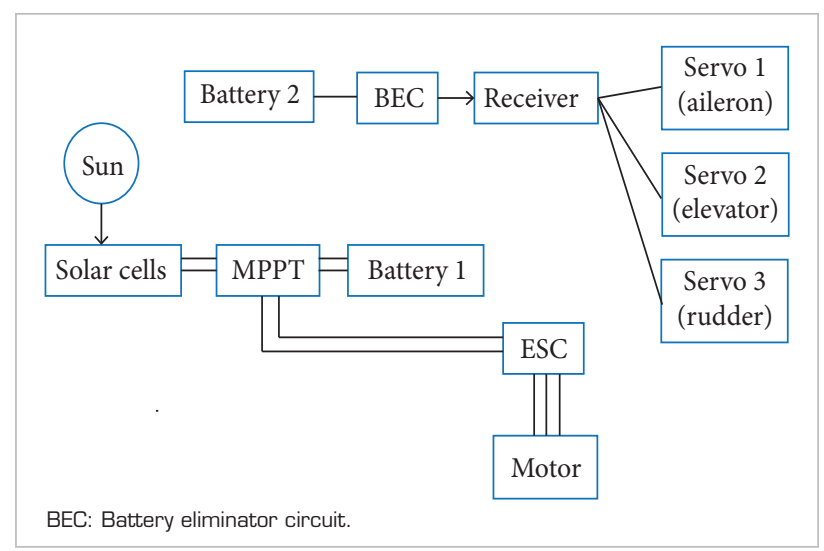

Figure 6. Circuit diagrams for entire plane.

\section{POWER REQUIRED FOR LEVEL FLIGHT}

At steady level flight, the lift force generated by the wing exactly compensates for the weight, and the propeller thrust, for the drag force (Simons 1994).

$$
\mathrm{W}=\mathrm{mg}=\mathrm{L}=\frac{\rho}{2} \mathrm{C}_{\mathrm{L}} \mathrm{SV}^{2}
$$

where: $m$ is the mass of the aircraft $(\mathrm{kg}) ; L$ is the lift force; $\rho$ is the air density $\left(\mathrm{kg} \cdot \mathrm{m}^{-3}\right) ; S$ is the surface area of the wing $\left(\mathrm{m}^{2}\right) ; V$ is the cruise velocity of the aircraft $\left(\mathrm{m} \cdot \mathrm{s}^{-1}\right)$. 
The axial thrust is calculated as:

$\mathrm{T}=\mathrm{D}=\frac{\rho}{2} \mathrm{C}_{\mathrm{D}} \mathrm{SV}^{2}$

where: $D$ is the drag force.

The induced drag is obtained as:

$\mathrm{C}_{\mathrm{Di}}=\frac{C_{L}^{2}}{\pi * \mathrm{e} * \mathrm{AR}} ; \mathrm{C}_{\mathrm{D}}=\mathrm{c}_{\mathrm{d}}+\mathrm{C}_{\mathrm{Di}}$

where: $c_{d}$ is the coefficient of drag of airfoil.

From Bandel et al. (2015), e means Oswald's efficiency, equal to $1.78 \times\left(1-0.045 \times A R^{0.68}\right)-0.64$. The power required for level flight is:

$$
\mathrm{P}_{\text {req }}=\mathrm{T} \times \mathrm{V}
$$

The required parameters for calculating the level flight are shown in Table 4. As the mass of the plane was initially fixed as $2 \mathrm{~kg}$, the total weight of the plane becomes $19.6 \mathrm{~N}$. From the above two equations, the cruise velocity of the plane that can be obtained as the lift coefficient for the airfoil is 0.91 , and the surface area of the wing can be calculated as the chord equal to $30 \mathrm{~cm}$ and the length of $2.63 \mathrm{~m}$, which is $0.8 \mathrm{~m}^{2}$. Hence, the velocity of the plane at cruise is $7.5585 \mathrm{~m} \cdot \mathrm{s}^{-2}$. The total drag is the sum of 3 drags: one caused by the wing $c_{d}$, which is around $0.2479 \mathrm{~N}$; the other is the induced drag, which accounts for $0.7855 \mathrm{~N}$ due to very high lift; and the last one is due to the body (fuselage), which is taken 1.7 times the airfoil drag. Then, the total drag for the entire plane is $1.4646 \mathrm{~N}$. From the total drag force and the cruise velocity, one can find the power required for a cruise: $P_{r e q}=T \times V=10.13 \mathrm{~W}$.

In order to get this much power, more power should be extracted from batteries as there are electronics in the circuit for which there will be losses during conversion and

Table 4. Required parameters for calculating level flight.

\begin{tabular}{|c|c|}
\hline Parameters & SI units \\
\hline Gross weight & $2 \mathrm{~kg}$ \\
\hline Gravity & $9.81 \mathrm{~m} \cdot \mathrm{s}^{-2}$ \\
\hline Airfoil lift coefficient & 0.91 \\
\hline Airfoil chord & $0.3 \mathrm{~m}$ \\
\hline Surface area of wing & $0.7389 \mathrm{~m}^{2}$ \\
\hline Airfoil drag coefficient & 0.0115 \\
\hline Aspect ratio & 9.36 \\
\hline Oswald's efficiency & 0.773 \\
\hline
\end{tabular}

efficiencies involved must be included: propeller efficiency of $80 \%$, motor efficiency of $80 \%$, ESC efficiency of $70 \%$ and the battery discharge efficiency of $90 \%$, so that it is obtained a total of $40.38 \%$. Here, extra $2 \mathrm{~W}$ are added to other losses. Hence, the total power required from the batteries is: (Power required for cruise/Battery to thrust efficiency) $+\mathrm{P}_{\text {other }}=27.11 \mathrm{~W}$.

The other circuit was from the battery to solar cells in which solar encapsulation was $90 \%$; solar cells, $22 \%$; camber efficiency, 90\%; MPPT efficiency, 90\%; and battery charging efficiency, $90 \%$, totaling $14.435 \%$. In order to get this power, the required solar irradiance is: Total power required from batteries/ (Sunlight to battery efficiency $\times$ Area of Solar cells $)=451.23 \mathrm{~W} \cdot \mathrm{m}^{-2}$. Hence, $451.23 \mathrm{~W} \cdot \mathrm{m}^{-2}$ of solar irradiance is required in order to have a level flight. Now, whether this much amount of solar irradiance is available from the Sun has to be determined.

\section{POWER AVAILABLE FROM SOLAR ENERGY}

Here, the power available from solar energy is calculated for April 1st, 2016 since April and May represent the hottest seasons in which maximum solar radiation occurs $(n=92$, as the numeric sequence starts with 1 for January $1^{\text {st }}$ ).

Then, the latitude $(\phi)$ of VIT Vellore, India, for the calculation, is $12.9692^{\circ}$. From this, the declination angle $(\delta)$ is calculated (Eq. 5), which represents the angular displacement of the Sun's rays at the north (or south) of the Equator and is the angle made by the Sun and the Earth with its projection on the equatorial plane.

$$
\delta=23.45 \sin \left(360 \frac{284+\mathrm{n}}{365}\right)
$$

By using latitude and declination angle, the hour angle $\left(\omega_{s}\right)$ can be found, which is the angle through which the Earth must turn to bring the meridian at a point directly in line with the Sun's rays. It is equivalent to $15^{\circ}$ per hour. From Jashnani et al. (2013):

$$
\omega_{\mathrm{s}}=\cos ^{-1}(\tan \phi \times \tan \delta)
$$

Thus, daily average irradiance $\left(H_{o}\right)$ is:

$$
\begin{aligned}
\mathrm{H}_{\mathrm{o}}= & \frac{24}{\pi} \mathrm{I}_{\mathrm{sc}} \times 3600\left(1+0.033\left(\cos \frac{360 \mathrm{n}}{365}\right)\right) \\
& \left(\omega_{\mathrm{s}} \cdot \sin \phi \cdot \sin \delta+\cos \phi \cdot \cos \delta \cdot \sin \omega_{\mathrm{s}}\right) \mathrm{kJ} / \mathrm{m}^{2} \cdot \text { day }
\end{aligned}
$$


where: $I_{s c}$ is the extra-terrestrial irradiance.

The day length or maximum sunshine hours can be found using:

$$
\mathrm{S}_{\max }=\frac{2}{15} \cos ^{-1}(-\tan \phi \cdot \tan \delta)
$$

which was for 12:13. Then, monthly average daily global radiation $(H)$ can be calculated for an altitude of $30 \mathrm{~m}$ and estimated using:

$$
\frac{\mathrm{H}}{\mathrm{H}_{\mathrm{o}}}=\mathrm{a}+\mathrm{b}\left(\frac{\mathrm{s}}{\mathrm{Smax}}\right)
$$

where: $a=-0.309+0.539 \cdot \cos \phi-0.0693 E+0.29\left(S / S_{\max }\right)$; $b=1.527-1.027 \cdot \cos \phi+0.0926 E-0.359\left(S / S_{\max }\right) ; S$ is the average sunshine hour per day; $E$ is the elevation of the location above mean sea level (200 m - Vellore).

At each hour of the day $(h)$, the instantaneous hour angle for a particular hour can be estimated as (in degrees):

$$
\omega=(15 h-180)
$$

The hourly global solar irradiance can be achieved (in $\mathrm{kJ} \cdot \mathrm{m}^{-2} \cdot$ day $^{-1}$ ) by using:

$$
\mathrm{I}_{\mathrm{g}}=\left[\frac{\pi}{24}(\mathrm{c}+\mathrm{d} \cdot \cos \omega) \frac{\cos \omega-\cos \mathrm{w}_{\mathrm{S}}}{\sin \mathrm{w}_{\mathrm{s}}-\frac{\pi \mathrm{w}_{\mathrm{S}}}{180} \cos \mathrm{w}_{\mathrm{s}}}\right] \times \mathrm{H}
$$

$$
\text { where: } c=0.409+0.516 \times \sin \left(\boldsymbol{\omega}_{s}-60\right)
$$

and $d=0.6609-0.4767 \times \sin \left(\omega_{s}-60\right)$.

The calculated solar parametric values are shown in Table 5 and, by calculating the instantaneous hour angle for a particular hour, global solar irradiance can be found for each solar hour; by taking the clear sky factor $\left(N_{\text {sky }}\right)$ as 0.7 , the readings in Table 6 are obtained for the entire day.

Table 5. Calculated solar parametric values.

\begin{tabular}{|c|c|}
\hline Parameter & SI units \\
\hline Declination angle & $4.4139^{\circ}$ \\
\hline Hour angle & $91.0186^{\circ}$ \\
\hline Daily average irradiance & $37,537 \mathrm{~kJ} \cdot \mathrm{m}^{-2} \cdot$ day $^{-1}$ \\
\hline Day length & $12.13 \mathrm{~h}$ \\
\hline Monthly average daily radiation & $24,266 \mathrm{~kJ} \cdot \mathrm{m}^{-2} \cdot$ day $^{-1}$ \\
\hline
\end{tabular}

From the graph shown in Fig. 7 and the data in Table 6, it is observed that, by using solar power alone, one is able to fly the plane for up to $5 \mathrm{~h}$. This flight time can be increased

\begin{tabular}{|c|c|c|c|}
\hline $\begin{array}{l}\text { Duration of } \\
\text { the day } \\
\text { (h] }\end{array}$ & $\begin{array}{l}\text { Global } \\
\text { radiation } \\
{\left[\mathbf{W} \cdot \mathrm{m}^{-2}\right]}\end{array}$ & $\begin{array}{c}\text { Estimated } \\
\text { radiation } \\
N_{\text {sky }}=\mathbf{0 . 7} \\
{\left[\mathrm{W} \cdot \mathrm{m}^{-2}\right]}\end{array}$ & $\begin{array}{l}\text { Power for } \\
\text { level flight } \\
{\left[\mathrm{W} \cdot \mathrm{m}^{-2}\right]}\end{array}$ \\
\hline $1-5$ & 0 & 0 & 451.23 \\
\hline 6 & 10.27 & 7.19 & 451.23 \\
\hline 7 & 185.72 & 130.0 & 451.23 \\
\hline 8 & 392.16 & 274.51 & 451.23 \\
\hline 9 & 602.52 & 421.76 & 451.23 \\
\hline 10 & 784.69 & 549.28 & 451.23 \\
\hline 11 & 908.41 & 635.89 & 451.23 \\
\hline 12 & 952.22 & 666.55 & 451.23 \\
\hline 13 & 908.41 & 635.89 & 451.23 \\
\hline 14 & 784.69 & 549.28 & 451.23 \\
\hline 15 & 602.52 & 421.76 & 451.23 \\
\hline 16 & 392.16 & 274.51 & 451.23 \\
\hline 17 & 185.72 & 130.0 & 451.23 \\
\hline 18 & 10.27 & 7.19 & 451.23 \\
\hline $19-24$ & 0 & 0 & 451.23 \\
\hline
\end{tabular}
as, during gliding, some amount of energy is stored in the battery.

Table 6. Estimated global solar radiation on April 1st, 2016 versus power required for level flight.

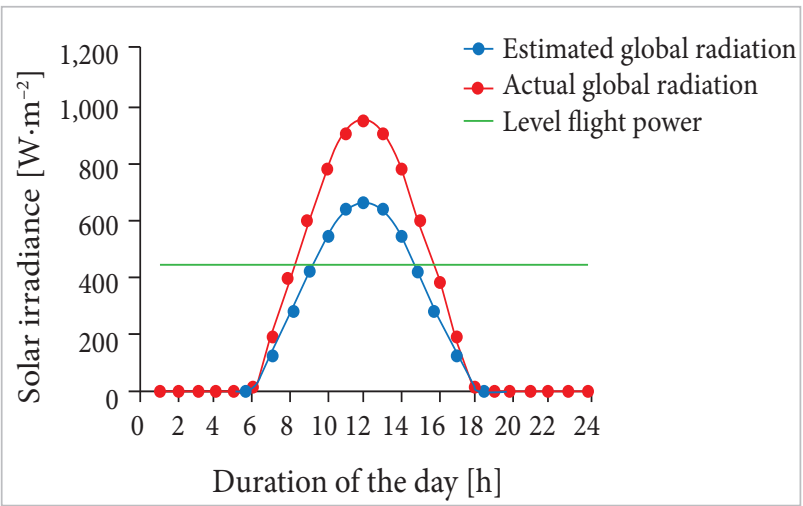

Figure 7. Duration of the day (April 1st, 2016) versus hourly global solar radiation — level flight power. 


\section{PRELIMINARY DESIGN DESIGN OF THE WING}

\section{Wing Configuration}

With respect to the angle made with the fuselage, from Fig. 8, the central part of the wing is perpendicular to the fuselage (straight) because it contains the solar cells and, in order to get maximum efficiency, these cells should be parallel to the ground; this kind of wing has high rigidity but poor roll stability. Hence, in order to have a good counter roll and lift, the ends of the main wing are extended by keeping a positive dihedral angle of $7^{\circ}$, which makes an obtuse angle with the main wing.

Regarding the position of the wing on the fuselage, a high wing is selected, which means it is situated over the fuselage; this kind of design helps in having high ground clearance, less interference drag, better field performance at low speeds and maximum space for having a payload.

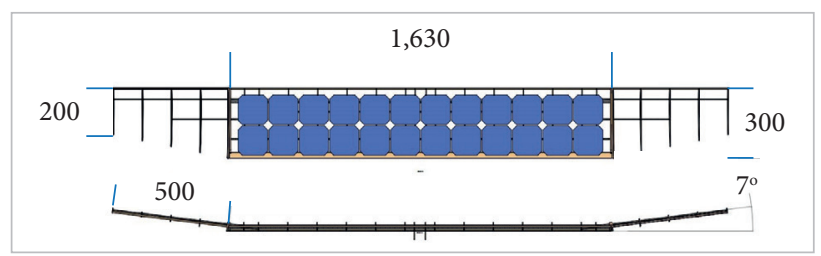

Figure 8. A draft model of the entire wing assembly.

\section{Taper Ratio}

It is the ratio $(\lambda)$ between the tip and the root chord of the wings. A trapezoidal shaped $(0<\lambda<1)$ is selected for the ends of the main wing. Wing tapering is used to improve lift distribution characteristics, which will also result in better lateral control since the mass moment of inertia of the wings around the longitudinal axis will be less. Here, $\lambda=0.66$.

$$
\lambda=\frac{C_{t}}{C_{r}}
$$

where: $C_{t}$ is the tip chord; $C_{r}$ is the root chord.

\section{Structure}

In the central part of the wing, the construction consists of spars, ribs, and the skin. As the central part of the wing is $0.0163 \mathrm{~m}$, which has solar cells integrated into it, the main priority is to achieve very small deflection. Then, 3 spars have been included, which are made of a carbon fiber (zoltac) material; two of them are $6 \times 4 \mathrm{~mm}$ and the middle one is $4 \times 2 \mathrm{~mm}$.
The spars will handle the tension and compression forces on the wing and are attached to the fuselage so they can transfer the forces to it; here, the forces will be spread over the entire construction. The ribs (made of lightweight balsa wood) are intended to give the wing the desired airfoil shape and also to stabilize the construction; they provide rigidity and strength to the wing by transferring the forces to the spars. The skin is also a part of the construction to resist the forces on the wing, which covers only the top surface with $1 \mathrm{~mm}$ of balsa sheet in order to make a non-conductive flat surface for the integration of solar cells.

The ends of the wing are tapered from a root chord of $30 \mathrm{~cm}$ to a tip chord of $20 \mathrm{~cm}$ over a length of $50 \mathrm{~cm}$. This part of the wings includes ailerons in order to have stability and control over the plane; In these parts, two carbon fiber spars are kept in order to give support and help in integrating the tapered parts to the main wing, since, at the junction of two parts of the wing, large forces will act. In Fig. 12, all dimensions are in $\mathrm{mm}$.

\section{DESIGN OF THE TAIL}

The airfoil selected for the horizontal and vertical tail is the NACA 0009 (Fig. 9) because it has a symmetrical profile in nature and a maximum lift coefficient of 0.8 . For the horizontal tail, the mean chord length is $0.205 \mathrm{~m}$ and, for the vertical one, the mean chord length is $0.25 \mathrm{~m}$ (AirfoilTools.com 2016).

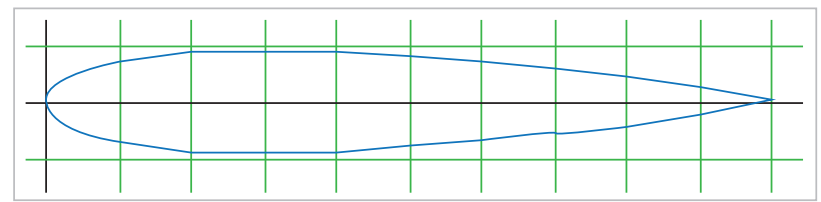

Figure 9. NACA 0009 airfoil shape.

\section{Horizontal Tail}

The dominant factors which control the aircraft pitch stability are gravity center (GC) position and horizontal tail size and position. The effectiveness of horizontal tail is measured by horizontal tail volume coefficient $\left(\mathrm{V}_{\mathrm{h}}\right)$ :

$$
\mathrm{V}_{\mathrm{h}}=\frac{\mathrm{S}_{\mathrm{h}} * \mathrm{~L}_{\mathrm{h}}}{\mathrm{S} * \mathrm{C}}
$$

where: $S_{h}$ is the horizontal tail area; $L_{h}$ is the distance from the tail's aerodynamic center (more of which later) to the 
aircraft's GC; $S$ is the wing area; $c$ is the mean aerodynamic chord.

After several iterations, the horizontal stabilizer parameters are shown in Table 7.

Table 7. Horizontal tail configuration.

\begin{tabular}{|c|c|}
\hline Horizontal stabilizer parameter & SI units \\
\hline Area $\left(S_{h}\right)$ & $0.14 \mathrm{~m}^{2}$ \\
\hline Moment arm $\left(L_{h}\right)$ & $0.96 \mathrm{~m}$ \\
\hline Volume coefficient $\left(V_{h}\right)$ & 0.64 \\
\hline Span $\left(b_{h}\right)$ & $0.7 \mathrm{~m}$ \\
\hline Mean chord $\left(c_{h}\right)$ & $0.205 \mathrm{~m}$ \\
\hline Taper ratio $\left(\lambda_{h}\right)$ & 1.0 \\
\hline Aspect ratio $\left(A R_{h}\right)$ & 3.41 \\
\hline Elevator ratio $\left(S_{r} / S_{h}\right)$ & 0.3 \\
\hline
\end{tabular}

\section{Vertical Tail}

The role of vertical tail is to control the yaw movement by providing yaw damping. The effectiveness of vertical tail is measured by the vertical tail coefficient $\left(V_{v}\right)$ :

$$
\mathrm{V}_{\mathrm{v}}=\frac{\mathrm{S}_{\mathrm{v}} * \mathrm{~L}_{\mathrm{v}}}{\mathrm{S} * \mathrm{~b}}
$$

where: $S_{v}$ is the vertical tail area; $L_{v}$ is the distance from the vertical tail's aerodynamic center to the aircraft's GC; $b$ is the wingspan.

After several iterations, the vertical stabilizer parameters are shown in Table 8. In Fig. 10, all dimensions are in $\mathrm{mm}$.

\section{FUSELAGE}

This part is designed after a number of iterations in order to improve the lift-to-drag ratio. The trails shown in Table 9 are analyzed in fluent software as shown in Fig. 11, respectively, for

Table 8. Vertical tail configuration.

\begin{tabular}{|c|c|}
\hline Vertical stabilizer parameters & SI units \\
\hline Area $\left(S_{v}\right)$ & $0.075 \mathrm{~m}^{2}$ \\
\hline Moment arm $\left(L_{v}\right)$ & $0.85 \mathrm{~m}$ \\
\hline Volume coefficient $\left(V_{v}\right)$ & 0.0328 \\
\hline Span $\left(b_{v}\right)$ & $0.3 \mathrm{~m}$ \\
\hline Mean chord $\left(c_{v}\right)$ & $0.25 \mathrm{~m}$ \\
\hline Aspect ratio $\left(A R_{v}\right)$ & 2.4 \\
\hline Taper ratio $\left(\lambda_{l}\right)$ & 1.0 \\
\hline Rudder ratio $\left(S_{r} / S_{v}\right)$ & 0.3 \\
\hline
\end{tabular}

a Reynolds number of 150,000 and by using SST $k$ - $\omega$ viscous model. The boundary conditions are given in Table 10 .

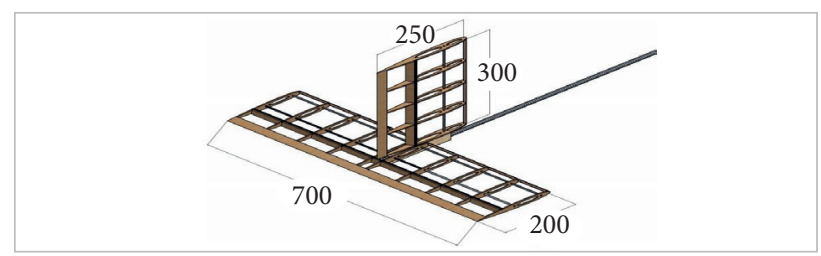

Figure 10. A draft model of the entire tail assembly.

Table 9. Comparison of $L / D$ for different trails.

\begin{tabular}{|c|c|c|}
\hline Trail number & Design modification & $L / D$ \\
\hline 1 & Basic cuboidal & 15.244 \\
\hline 2 & Tapered front and back & 15.498 \\
\hline 3 & Lightly streamlined & 15.72 \\
\hline 4 & Final design & 15.81 \\
\hline
\end{tabular}

Table 10. Boundary conditions.

\begin{tabular}{|c|c|c|}
\hline Edge & $\begin{array}{c}\text { Type of } \\
\text { boundary }\end{array}$ & Boundary condition \\
\hline Inlet & Velocity & $8 \mathrm{~m} \cdot \mathrm{s}^{-1}(x$ direction $)$ \\
\hline Outlet & Pressure & Gauge pressure $=0 \mathrm{~Pa}$ \\
\hline Wall & Stationary & Velocity $=0 \mathrm{~m} \cdot \mathrm{s}^{-1}$ \\
\hline
\end{tabular}

(a)

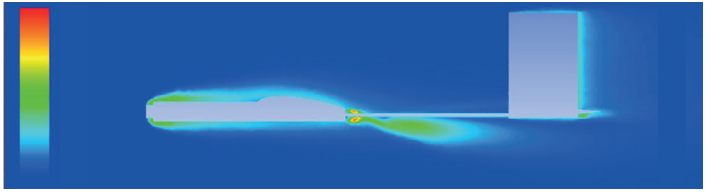

(b)

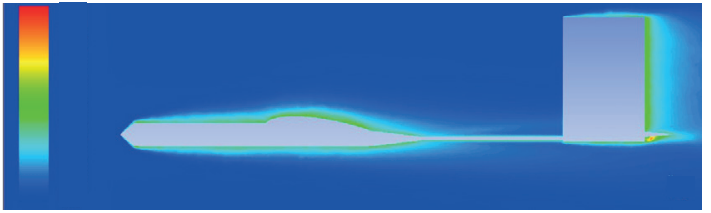

(c)

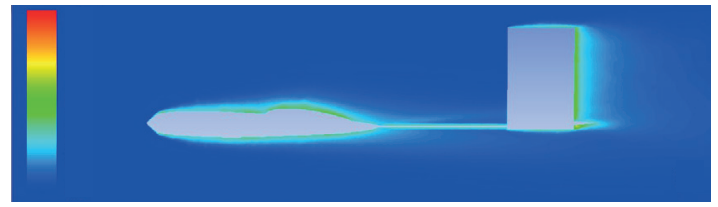

d)

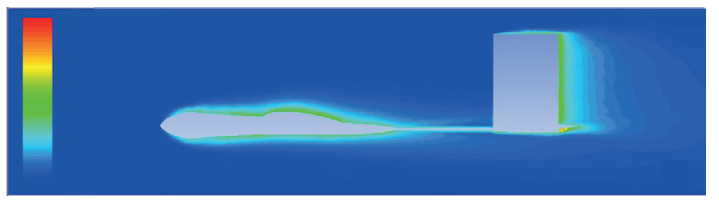

Figure 11. (a) Basic cuboidal (Trail 1); (b) Tapered ends (Trail 2); (c) Streamlined (Trail 3); (d) Final design (Trail 4). 
The final design is selected, having a lift force of $18.06 \mathrm{~N}$ and a drag one of $1.142 \mathrm{~N}$. The primary function of the fuselage is to carry the electronics and payload. Hence, a length of $0.65 \mathrm{~m}$ and $0.82 \mathrm{~m}$ in width and height are obtained for the design. The propulsion system components can be mounted in the front of the fuselage, and the electronics and payload may be shifted back or fronted in such a way to adjust the center of gravity position of the plane, which is at a distance of $9 \mathrm{~cm}$ from the leading edge of the wing. The tail boom is connected to the back of the fuselage, which is integrated to the main wing through carbon fiber rods. In Fig. 12, all dimensions are in meters. Finally, all parts are assembled forming the complete plane, as shown in Fig. 13, in which all the dimensions are in $\mathrm{mm}$.

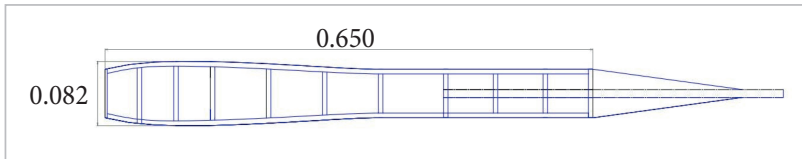

Figure 12. A draft model of the fuselage.

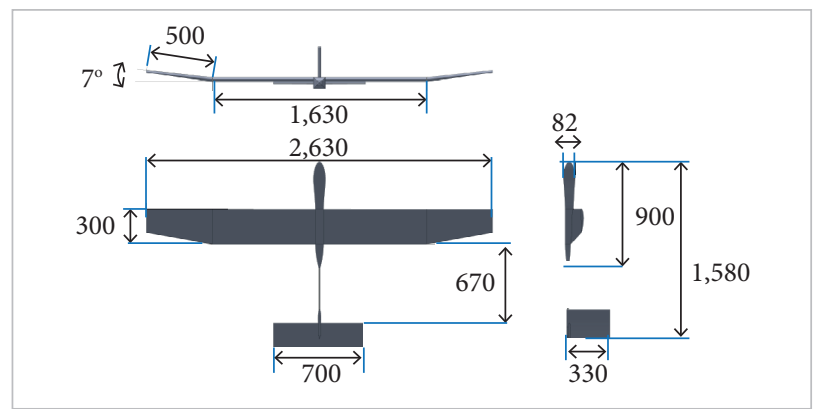

Figure 13. Entire plane draft model.

\section{STRUCTURAL ANALYSIS}

The two primary structures for the design are the wing spar and the tail boom. Both of these are analyzed in detail so they could be lightweight but strong enough to support the design loads. The wing spar has to carry 3 primary loads: the wing bending load produced by lift, the transverse shear load caused by wing bending, and the torque load produced by the pitching moment of the wing airfoil. The tail boom has to carry the bending loads produced by the horizontal and vertical stabilizers.

The wing spar and tail boom are made of carbon fiber material which can support very high loads before they fail. For aerodynamic surfaces, even a small amount of deformation could potentially upset the stability or control of the airplane. Calculating the structural deformation using an analytical method would have been impractical. Instead, the potential approach is to use finite element analysis to determine how the structures are deformed.
A software has been used to find the deflection and stress using finite element method. In order to validate it, we took a problem which can be solvable by the analytical approach and compared it with the software results.

For the validation, a problem (Bansal 2010) has been solved both manually and in the software; the deviation was found to be less than $5 \%$. Then, for further complex analyses, the software is used to find the results. The input properties for balsa wood (MakeitFrom.com 2016) and carbon fiber (GoodWinds Composites 2016) have been taken for all the analyses.

In the wing deformation, the mid wing excluding the tapered parts is analyzed since mostly the lift force is acted only on the middle section of the wing. Then, a load of $4 \mathrm{~kg}$ is applied to the entire wing, taking a factor of safety equal to 2 and keeping the central position of about $10 \mathrm{~cm}$ constant since that portion is fixed to the fuselage, as shown in Fig 14. A deflection of only $1.4 \mathrm{~cm}$ is observed.

The tail boom has to resist to bending loads, keeping the empennage surfaces at the proper aerodynamic incidence with the wing. If the tail boom flexed too much, control effectiveness would be reduced. Bending load is the greatest on the tail boom when the empennage surfaces operate at a high lift coefficient and the aircraft is flying at a high speed. The bending load on the tail boom could be treated as a point load acting at the end of the tail boom and its critical value can be calculated as:

$$
\mathrm{P}_{\text {crit }}=(0.5) \rho \mathrm{V}^{2} \mathrm{~S}_{\mathrm{h}} \mathrm{C}_{\mathrm{Lmax}}
$$

The critical bending load characteristics for the tail boom are shown in Table 11. A bending load that we got from the calculation of $4.4 \mathrm{~N}$ is applied on one end of the tail, keeping the other end constant. A deflection of $0.8 \mathrm{~cm}$ is observed.

The fuselage has to carry the payload and electronics, which can weight more than $1 \mathrm{~kg}$. Hence, a force of $30 \mathrm{~N}$, which is

Table 11. Critical bending load characteristics for tail boom.

\begin{tabular}{|c|c|}
\hline Parameter & SI unit \\
\hline Velocity $(V)$ & $8 \mathrm{~m} \cdot \mathrm{s}^{-1}$ \\
\hline Air density $(\rho)$ & $1.227 \mathrm{~kg} \cdot \mathrm{m}^{-3}$ \\
\hline Horizontal stabilizer area $\left(S_{h}\right)$ & $0.14 \mathrm{~m}^{2}$ \\
\hline Max tail coefficient $\left(C_{L \max }\right)$ & 0.8 \\
\hline Critical bending load $\left(P_{\text {crit }}\right)$ & $4.4 \mathrm{~N}$ \\
\hline Tail boom $(L)$ & $0.6 \mathrm{~m}$ \\
\hline Modulus of elasticity $(E)$ & $131 \mathrm{Gpa}$ \\
\hline
\end{tabular}


$3 \mathrm{~kg}$ (more than the entire plane weight), is applied to the front section by keeping the end section fixed, as shown in Fig 15. A deformation of $0.279 \mathrm{~cm}$ is observed.

Concerning the stress analysis, the fuselage is analyzed to find out whether the stress is below the permissible range or not for a load of $30 \mathrm{~N}$. Besides, according to the analysis, as shown in Fig. 16, a von Mises stress of 4.4 MPa is observed, which is within the permissible value of 9.6 $\mathrm{MPa}$.

In the middle section of the wing, more stress is acted on the carbon fiber rods than that of balsa ribs and skin for a force of $40 \mathrm{~N}$, as shown in Fig. 17. Nevertheless, the stress which is acted on carbon rods is negligible when compared to its permissible stress. The red portion is only observed on the carbon fiber rods, whereas the balsa wood portion is blue in a color which is the minimum stress. Hence, all the parts are under the safer limit even under a factor of safety equal to 2 .

\section{RESULTS AND CONCLUSION}

In this paper, the suitable airfoil has been chosen by analyzing different airfoils from previous designs for a high

A: static structural

Total deformation

Type: total deformation

Unit: $\mathrm{m}$

Time: 1

04-Apr-2016 12:57 p.m.

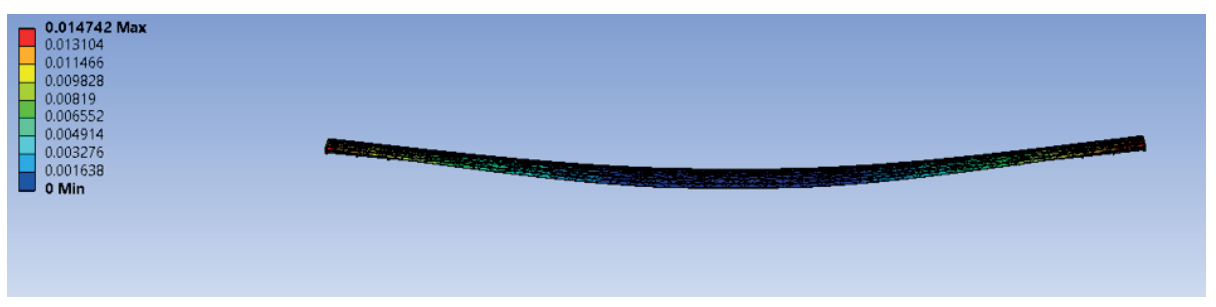

Figure 14. Deflection of mid-wing.

B: static structural Total deformation

Type: total deformation

Unit: $\mathrm{m}$

Time: 1

07-Apr-2016 7:02 p.m.

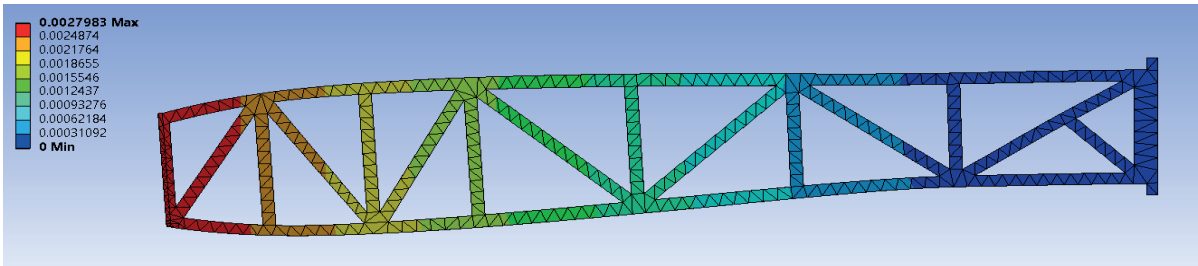

Figure 15. Deflection of the fuselage.

B: static structural

Equivalent stress

Type: equivalent

(von Mises) stress

Unit: $\mathrm{MPa}$

Time: 1

07-Apr-2016 11:36 p.m.

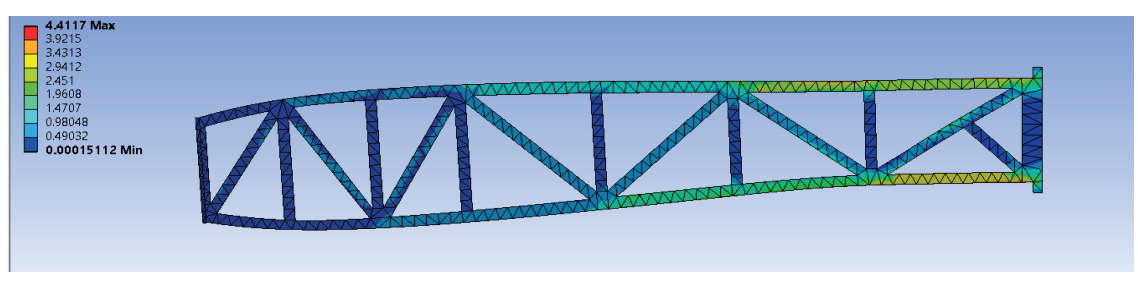

Figure 16. Von Mises stress analysis of the fuselage.

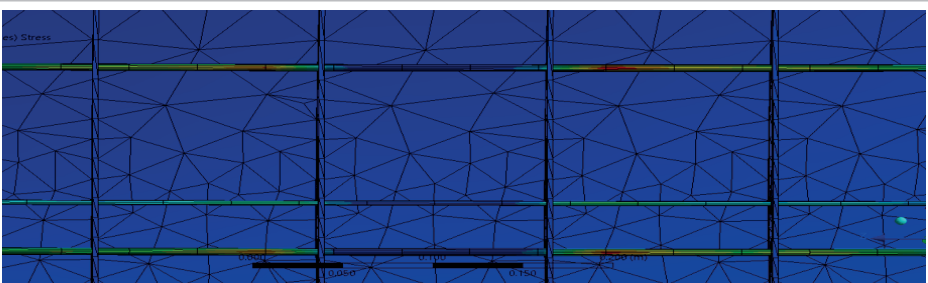

Figure 17. An enlarged view of stress region near the middle portion of the mid-wing. 
lift-to-drag ratio. It was presented a way to calculate a number of solar cells required for giving enough power to the motor lift the 2-kg plane, which can extend for heavier ones. It was performed detailed energy and power analysis to check whether the design would be feasible or not. Then, all the components were designed, considering various factors for better performance, and analyzed for deflection and stress to keep the design under the safer limit. This gives a basic foundation in order to fabricate a solar-powered UAV.

\section{ACKNOWLEDGEMENTS}

We wish to express our profound gratitude and indebtedness to Prof. M. Natarajan, for his inspiring guidance, and Prof.
Arivazhagan $\mathrm{N}$, for granting permissions to use the required equipment during the course of this research. We would also like to show our gratitude to Team Vimaanas, VIT University, which provided insight and expertise that greatly assisted the research.

\section{AUTHOR'S CONTRIBUTION}

Aneesh $\mathrm{P}$ was responsible for conceptual study and design. Data acquisition, analysis and drafting were carried out by Reddy BSK. Bhanu K and Natarajan M performed solar cells experimentation and interpretation of data. All authors discussed the results and commented on the manuscript.

\section{REFERENCES}

AirfoilTools.com (2016) Airfoil tools; [accessed 2016 Aug 11]. http://airfoiltools.com/index

Bandel A (2015) Aviation studies design build and fly minor. Amsterdam: University of Applied Sciences.

Bansal RK (2010) A textbook of the strength of materials. Bangalore: Laxmi Publications.

Bruscoli S (2011) Airfoil optimization for a solar powered aircraft (PhD thesis]. Pisa: Università degli Studi di Pisa.

GoodWinds Composites (2016) Carbon rods; [accessed 2016 Aug 11]. Available: http://gwcomposites.com/carbon-rods/

Jashnani S, Nada TR, Ishfaq M, Khamker A, Shaholia P (2013) Sizing and preliminary hardware testing of solar-powered UAV. The Egyptian Journal of Remote Sensing and Space Sciences 16(2):189-198. doi: 10.1016/j.ejrs.2013.05.002
Kederoglu OG, Yanbastioglu S, Saraç B, Kocaoğlan MH (2012) Solar powered aircraft: PV Power System Definition \& Solution Development Project; [accessed 2016 Aug 11]. http://www. academia.edu/7515954/Solar_Powered_Aircraft_Project

Kumar G, Sepat S, Bansal S (2015) Review paper of solar-powered UAV. International Journal of Scientific \& Engineering Research 6(2):41-44.

MakeitFrom.com (2016) Balsa; [accessed 2016 Aug 11]. http:// www. makeitfrom.com/material-properties/Balsa/

Noth A (2008) Design of solar powered airplanes for continuous flight (PhD thesis]. Zürich: ETH Zürich.

Simons M (1994) Model aircraft aerodynamics. 3rd edition. Hemel Hempstead: Argus. 